\title{
M1 Extra Weight in the Balance: The Role of Macrophages in Obesity
}

\author{
Cristhiane Favero de Aguiar and Pedro M Mendes Moraes Vieira* \\ Department of Genetics, Evolution, Microbiology and Immunology, Institute of Biology, University of Campinas (UNICAMP), Brazil
}

Submission: May 18, 2018; Published: June 19, 2018

*Corresponding author: Pedro M Mendes Moraes Vieira, Department of Genetics, Evolution, Microbiology and Immunology, Institute of Biology -Rua Monteiro Lobato, 255, Bloco H -Campinas-SP, CEP: 13083-862, Brazil, Tel: +551935216121; Email: pmvieira@unicamp.br

\begin{abstract}
Obesity affects millions of people worldwide and is a complex and multifactorial syndrome. Alterations in eating habits and lifestyle in developed countries increased obesity rates drastically through the past years and also the deaths associated with this condition. The immune system is an important component to maintain adipose tissue homeostasis and also to promote inflammation during obesity. In this mini review, we will briefly describe the main factors that contribute to systemic low-grade inflammation in obesity and lead to insulin resistance.
\end{abstract}

Keywords: Obesity; Macrophages; Inflammation; Adipose tissue

\section{Introduction}

Obesity is a condition characterized by excessive fat accumulation that has become a worldwide epidemic problem. According to the World Health Organization, in 2016, over 650 million adults were obese [1]. It is noteworthy that overweight and obesity are related to several diseases, such as cardiovascular diseases, diabetes and some cancers [1,2]. Another important correlation exists between obesity and the immune system, where obesity is strongly associated with systemic low-grade inflammation.

\section{Obesity and inflammation}

The link between obesity and inflammation has been studied since the 90's with the discovery that TNF- $\alpha$ was augmented in obesity and associated with insulin resistance [3]. From there to here, innumerous studies have demonstrated the importance of the immune system in obesity [4-8]. During obesity development, the adipose tissue functions not only as a reservoir of fat but also as an endocrine and immune organ, being capable of producing hormones, lipids, adipokines and proinflammatory cytokines [914].

Two important adipokines related to obesity are adiponectin and leptin. Adiponectin is an anti-inflammatory adipokine that can act on immune cells to inhibit the production of TNF- $\alpha$ and IL- 6 and induce the production of Il-10 and IL-1RA. In line with that, adiponectin is known as an insulin sensitizer, being observed that adiponectin knockout mice have increased insulin resistance and overexpression of adiponectin can induce insulin sensitivity in diet-induced obese mice [15-17]. In contrast, leptin is considered a proinflammatory adipokine due to its actions on immune cells to promote activation, secretion of TNF- $\alpha$, IL-1, IL12 , nitric oxide and downregulate the production of IL-10 [4,1822].

Furthermore, immune cells play a major role in adipose tissue inflammation since resident and infiltrating inflammatory cells expand in the adipose tissue during obesity and take part on systemic inflammation due to their production of TNF- $\alpha$, IL-6, IL-1 $\beta$ and other factors $[23,24]$.

\section{Macrophages, obesity and insulin resistance}

Macrophages are important players in innate immunity and also in the context of systemic low-grade inflammation associated to obesity. The finding that monocytes infiltrate the adipose tissue and differentiate into macrophages was an important step to unveil the role of macrophages in obesity and its associated inflammation $[23,25,26]$.

Macrophages can be subdivided in two main subtypes: M1 and M2 macrophages. M1 or classically activated macrophages are induced by IFN $-\gamma$ and LPS, and produce mainly proinflammatory cytokines, as TNF- $\alpha$ and IL-6, while M2 or alternativelyactivated macrophages are induced by IL-4 and produce primarily IL-10 [27,28]. Because of their production of proinflammatory cytokines, M1 macrophages are associated with the promotion of Th1 response, microbicidal activity, tissue 


\section{Current Research in Diabetes \& Obesity Journal}

injury, enhanced glycolysis and tumor suppression. On the other hand, M2 macrophages orchestrate tissue repair/remodeling and promote angiogenesis and tumor progression [29-31].

Both M1 and M2 macrophages can be found in the adipose tissue, with increased numbers of M2 macrophages in lean conditions [32]. In normal weight, the lean adipose tissue microenvironment is associated with either increased levels of adiponectin, which enhances insulin sensitivity and increases M2 polarization, and with increased number of regulatory $\mathrm{T}$ cells that also promote M2 differentiation through the production of IL-10 and TGF- $\beta$ and maintain tissue homeostasis [33-35] However, in obese conditions, the ratio between M1/M2 shifts toward a proinflammatory profile, with infiltration of monocytes that differentiate into M1 macrophages in the adipose tissue [32]. These proinflammatory macrophages have unique surface markers, as CD11c, and respond to cytokines, free fatty acids, triglycerides, leptin, retinol-binding protein 4 (RBP4) and other factors present in the obese adipose tissue milieu [6,9,36,37]. During obesity, several proinflammatory pathways are triggered in both macrophages and adipocytes, as the c-Jun NH2-terminal kinase (JNK 1 and 2) [38], extracellular signal-regulated kinase 1 and 2 (ERK 1 and 2) [39], inhibitor of $\kappa B$ kinase (IKK) [40] and mitogen-activated protein kinase p38 (p38 MAPK), which are responsible for alterations in the insulin receptor signaling pathwaysthat lately contribute to insulin resistance $[8,41]$. Tolllike receptors (TLRs) and inflammasomes are also important components for the inflammatory response in the adipose tissue. During obesity, increased expression of TLRs and inflammasomes in adipose tissue macrophages enhances the secretion ofTNF- $\alpha$ and IL-1 $\beta$, which further exacerbate inflammation [42-44]. TLRs can signal through an adaptor molecule called Myd88 (for myeloid differentiation primary response gene 88 ) and recently, Castoldi and colleagues described a new role for Myd88 in obesity and insulin resistance [45]. They demonstrated that in the absence of Myd88 there is an upregulation of dectin-1 in adipose tissue macrophages, which correlates with exacerbated obesity and increased insulin resistance [45]. In this sense, treating mice with dectin-1 inhibitor decreased M1 macrophages in the adipose tissue and ameliorated insulin resistance [45]. Still, in the context of TLR signaling pathway, for several years it was believed that TLR4 could be activated by saturated fatty acids, which triggered macrophage activation and contribute to adipose tissue inflammation during obesity [43,46-48]. Nevertheless, Lancaster and colleagues recently demonstrated that the inflammatory fatty acid palmitate is actually not a TLR4 agonist; instead, palmitate induces macrophage activation by altering macrophage metabolism [49].

Several components in the immune system influence the development of obesity and insulin resistance. However, obesity is a complex and multifactorial disease and the immune system is regulated by an intricate network of pathways cell interactions. Thus, the study of this network is still needed to unveil new concepts and paradigms.

\section{Conclusion}

Obesity is a relevant healthy issue that affects millions of people worldwide and leads to high morbidity and mortality with high costs to healthy systems. The immune system and specially macrophages are main players in aggravating obesity and inducing insulin resistance. Considerable studies were performed to elucidate the mechanisms by which immune cells, adipocytes and other factors work together to promote tissue inflammation. The understanding of adipose tissue physiology in lean and obesogenic conditions may lead to the development of new strategies and treatments for obesity and its-associated comorbidities.

\section{References}

1. WHO (2017) Global health observatory.

2. Van Gaal LF, Mertens IL, De Block CE (2006) Mechanisms linking obesity with cardiovascular disease. Nature 444(7121): 875-880.

3. Hotamisligil GS, Shargill NS, Spiegelman BM (1993) Adipose expression of tumor necrosis factor-alpha: direct role in obesity-linked insulin resistance. Science 259(5091): 87-91.

4. Andrade Oliveira V, Camara NO, Moraes Vieira PM (2015) Adipokines as drug targets in diabetes and underlying disturbances. J Diabetes Res 2015: 681612 .

5. Moraes Vieira PM, Bassi EJ, Larocca RA, Castoldi A, Burghos M, et al. (2013) Leptin deficiency modulates allograft survival by favoring a Th2 and a regulatory immune profile. [corrected]. Am J Transplant 13(1): 36-44.

6. Moraes Vieira PM, Saghatelian A, Kahn BB (2016) GLUT4 Expression in adipocytes regulates de novo lipogenesis and levels of a novel class of lipids with antidiabetic and anti-inflammatory effects. Diabetes 65(7): 1808-1815.

7. Pereira J, da Silva FC, de Moraes Vieira PMM (2017) The impact of ghrelin in metabolic diseases: an immune perspective. J Diabetes Res 2017: 4527980 .

8. Castoldi A, Naffah de Souza C, Camara NO, Moraes Vieira PM (2015) The macrophage switch in obesity development. Front Immunol 6 : 637.

9. Maachi M, Pieroni L, Bruckert E, Jardel C, Fellahi S, et al. (2004) Systemic low-grade inflammation is related to both circulating and adipose tissue TNFalpha, leptin and IL-6 levels in obese women. Int J Obes Relat Metab Disord 28(8): 993-997.

10. Kershaw EE, Flier JS (2004) Adipose tissue as an endocrine organ. J Clin Endocrinol Metab 89(6): 2548-2556.

11. Syed I, Lee J, Moraes Vieira PM, Donaldson CJ, Sontheimer A, et al (2018) Palmitic acid hydroxystearic acids activate GPR40, which is involved in their beneficial effects on glucose homeostasis. Cell Metab 27(2): 419e4-427e4.

12. Yore MM, Syed I, Moraes Vieira PM, Zhang T, Herman MA, et al. (2014) Discovery of a class of endogenous mammalian lipids with antidiabetic and anti-inflammatory effects. Cell 159(2): 318-332.

13. Moraes Vieira PM, Castoldi A, Aryal P, Wellenstein K, Peroni OD, et al. (2016) Antigen presentation and T-Cell activation are critical for RBP4-induced insulin resistance. Diabetes 65(5): 1317-1327.

14. Vijayakumar A, Aryal P, Wen J, Syed I, Vazirani RP, et al. (2017) Absence of carbohydrate response element binding protein in adipocytes causes systemic insulin resistance and impairs glucose transport. Cell Rep 21(4): 1021-1035. 


\section{Current Research in Diabetes \& Obesity Journal}

15. Fruebis J, Tsao TS, Javorschi S, Ebbets Reed D, Erickson MR, et al. (2001) Proteolytic cleavage product of $30-\mathrm{kDa}$ adipocyte complement-related protein increases fatty acid oxidation in muscle and causes weight loss in mice. Proc Natl Acad Sci USA 98(4): 2005-2010.

16. Bauche IB, El Mkadem SA, Pottier AM, Senou M, Many MC, et al. (2007) Overexpression of adiponectin targeted to adipose tissue in transgenic mice: impaired adipocyte differentiation. Endocrinology 148(4): 1539-1549.

17. Yamauchi T, Kamon J, Waki H, Imai Y, Shimozawa N, et al. (2003) Globular adiponectin protected ob/ob mice from diabetes and ApoEdeficient mice from atherosclerosis. J Biol Chem 278(4): 2461-2468.

18. Zarkesh Esfahani H, Pockley G, Metcalfe RA, Bidlingmaier M, Wu Z, et al. (2001) High-dose leptin activates human leukocytes via receptor expression on monocytes. J Immunol 167(8): 4593-4599.

19. Santos Alvarez J, Goberna R, Sanchez Margalet V (1999) Human leptin stimulates proliferation and activation of human circulating monocytes. Cell Immunol 194(1): 6-11.

20. Moraes Vieira PM, Bassi EJ, Araujo RC, Camara NO (2012) Leptin as a link between the immune system and kidney-related diseases: leading actor or just a coadjuvant? Obes Rev 13(8): 733-743

21. Moraes Vieira PM, Larocca RA, Bassi EJ, Peron JP, Andrade Oliveira V, et al. (2014) Leptin deficiency impairs maturation of dendritic cells and enhances induction of regulatory T and Th17 cells. Eur J Immuno 44(3): 794-806

22. Reis BS, Lee K, Fanok MH, Mascaraque C, Amoury M, et al. (2015) Leptin receptor signaling in T cells is required for Th17 differentiation. J Immunol 194(11): 5253-5260.

23. Amano SU, Cohen JL, Vangala P, Tencerova M, Nicoloro SM, et al. (2014) Local proliferation of macrophages contributes to obesity-associated adipose tissue inflammation. Cell Metab 19(1): 162-171.

24. Oh DY, Morinaga H, Talukdar S, Bae EJ, Olefsky JM (2012) Increased macrophage migration into adipose tissue in obese mice. Diabetes 61(2): 346-354

25. Kanda H, Tateya S, Tamori Y, Kotani K, Hiasa K, et al. (2006) MCP-1 contributes to macrophage infiltration into adipose tissue, insulin resistance, and hepatic steatosis in obesity. J Clin Invest 116(6): 1494 1505.

26. Masoodi M, Kuda O, Rossmeisl M, Flachs P, Kopecky J (2015) Lipid signaling in adipose tissue: connecting inflammation \& metabolism. Biochim Biophys Acta 1851(4): 503-518.

27. Mantovani A, Sica A, Sozzani S, Allavena P, Vecchi A, et al. (2004) The chemokine system in diverse forms of macrophage activation and polarization. Trends Immunol 25(12): 677-686.

28. Murray PJ, Allen JE, Biswas SK, Fisher EA, Gilroy DW, et al. (2014) Macrophage activation and polarization: nomenclature and experimental guidelines. Immunity 41(1): 14-20.

29. Gordon S, Martinez FO (2010) Alternative activation of macrophages: mechanism and functions. Immunity 32(5): 593-604.

30. Mantovani A, Biswas SK, Galdiero MR, Sica A, Locati M (2013) Macrophage plasticity and polarization in tissue repair and remodelling. J Pathol 229(2): 176-185.

31. Correa da Silva F, Pereira JAS, de Aguiar CF, de Moraes Vieira PMM (2017) Mitoimmunity-when mitochondria dictates macrophage function. Cell Biol Int 42(6): 651-655.

32. Lumeng CN, Bodzin JL, Saltiel AR (2007) Obesity induces a phenotypic switch in adipose tissue macrophage polarization. J Clin Invest 117(1): 175-184.
33. Feuerer M, Herrero L, Cipolletta D, Naaz A, Wong J, et al. (2009) Lean, but not obese, fat is enriched for a unique population of regulatory $\mathrm{T}$ cells that affect metabolic parameters. Nat Med 15(8): 930-939.

34. Chawla A, Nguyen KD, Goh YP (2011) Macrophage-mediated inflammation in metabolic disease. Nat Rev Immunol 11(11): 738-749.

35. Kang YE, Kim JM, Joung KH, Lee JH, You BR, et al. (2016) The Roles of adipokines, proinflammatory cytokines, and adipose tissue macrophages in obesity-associated insulin resistance in modest obesity and early metabolic dysfunction. PLoS One 11(4): e0154003.

36. Moraes Vieira PM, Yore MM, Dwyer PM, Syed I, Aryal P, et al. (2014) RBP4 activates antigen-presenting cells, leading to adipose tissue inflammation and systemic insulin resistance. Cell Metab 19(3): 512526.

37. Zemany L, Bhanot S, Peroni OD, Murray SF, Moraes Vieira PM, et al. (2015) Transthyretin antisense oligonucleotides lower circulating RBP4 levels and improve insulin sensitivity in obese mice. Diabetes 64(5): 1603-1614.

38. Han MS, Jung DY, Morel C, Lakhani SA, Kim JK, et al. (2013) JNK expression by macrophages promotes obesity-induced insulin resistance and inflammation. Science 339(6116): 218-222.

39. Banks AS, McAllister FE, Camporez JP, Zushin PJ, Jurczak MJ, et al. (2015) An ERK/Cdk5 axis controls the diabetogenic actions of PPARgamma. Nature 517(7534): 391-395.

40. Gao Z, Hwang D, Bataille F, Lefevre M, York D, et al. (2002) Serine phosphorylation of insulin receptor substrate 1 by inhibitor kappa $B$ kinase complex. J Biol Chem 277(50): 48115-48121.

41. Carlson CJ, Koterski S, Sciotti RJ, Poccard GB, Rondinone CM (2003) Enhanced basal activation of mitogen-activated protein kinases in adipocytes from type 2 diabetes: potential role of p38 in the downregulation of GLUT4 expression. Diabetes. 52(3): 634-641.

42. Davis JE, Gabler NK, Walker Daniels J, Spurlock ME (2008) Tlr-4 deficiency selectively protects against obesity induced by diets high in saturated fat. Obesity (Silver Spring) 16(6): 1248-1255.

43. Shi H, Kokoeva MV, Inouye K, Tzameli I, Yin H, et al. (2006) TLR4 links innate immunity and fatty acid-induced insulin resistance. J Clin Invest 116(11): 3015-3025.

44. Vandanmagsar B, Youm YH, Ravussin A, Galgani JE, Stadler K, et al. (2011) The NLRP3 inflammasome instigates obesity-induced inflammation and insulin resistance. Nat Med 17(2): 179-188.

45. Castoldi A, Andrade Oliveira V, Aguiar CF, Amano MT, Lee J, et al. (2017) Dectin-1 activation exacerbates obesity and insulin resistance in the absence of my D88. Cell Rep 19(11): 2272-2288.

46. Caesar R, Tremaroli V, Kovatcheva Datchary P, Cani PD, Backhed F (2015) Crosstalk between gut microbiota and dietary lipids aggravates WAT inflammation through TLR signaling. Cell Metab 22(4): 658-668.

47. Huang S, Rutkowsky JM, Snodgrass RG, Ono Moore KD, Schneider DA, et al. (2012) Saturated fatty acids activate TLR-mediated proinflammatory signaling pathways. J Lipid Res 53(9): 2002-2013.

48. Lee JY, Sohn KH, Rhee SH, Hwang D (2001) Saturated fatty acids, but not unsaturated fatty acids, induce the expression of cyclooxygenase-2 mediated through Toll-like receptor 4. J Biol Chem 276(20): 1668316689.

49. Lancaster GI, Langley KG, Berglund NA, Kammoun HL, Reibe S, et al. (2018) Evidence that TLR4 is not a receptor for saturated fatty acids but mediates lipid-induced inflammation by reprogramming macrophage metabolism. Cell Metab 27(5): 1096e5-110e5. 
(C) This work is licensed under Creative Commons Attribution 4.0 Licens

DOI: 10.19080/CRDOJ.2018.07.555717
Your next submission with Juniper Publishers will reach you the below assets

- Quality Editorial service

- Swift Peer Review

- Reprints availability

- E-prints Service

- Manuscript Podcast for convenient understanding

- Global attainment for your research

- Manuscript accessibility in different formats

( Pdf, E-pub, Full Text, Audio)

- Unceasing customer service

Track the below URL for one-step submission https://juniperpublishers.com/online-submission.php 